PAPER

\title{
Testing ground GDR: Western pharmaceutical firms conducting clinical trials behind the Iron Curtain
}

\author{
Rainer Erices, ${ }^{1}$ Andreas Frewer, ${ }^{1}$ Antje Gumz ${ }^{2,3}$
}

${ }^{1}$ Institut für Geschichte und Ethik der Medizin, FriedrichAlexander-Universität ErlangenNuernberg, Erlangen, Germany ${ }^{2}$ Institut und Poliklinik für Psychosomatische Medizin und Psychotherapie,

Universitaetsklinikum Hamburg-Eppendorf, Hamburg, Germany

${ }^{3}$ Psychologische Hochschule Berlin (PHB), Berlin, Germany

\section{Correspondence to} Dr Rainer Erices, Institut für Geschichte und Ethik der Medizin, Friedrich-AlexanderUniversität Erlangen-

Nuernberg, Glueckstraße 10, Erlangen D-91054, Germany; rainer@erices.de

Received 14 November 2013 Revised 6 August 2014 Accepted 29 August 2014 Published Online First 23 October 2014
CrossMark

\begin{tabular}{l}
\hline To cite: Erices R, Frewer A, \\
Gumz A. J Med Ethics \\
2015;41:529-533. \\
\hline
\end{tabular}

\section{ABSTRACT}

Western pharmaceutical companies conducted clinical trials in the Eastern Bloc during the Cold War. Recently, media reports about alleged human experimentation provoked a wave of indignation. However, a scientific and objective account of these trials is lacking. The aim of this study was to describe and evaluate the clinical trials performed in the German Democratic Republic (GDR) based on archival material from the health system and the secret service. We found documents relating to 220 trials involving more than 14000 patients and 68 Western companies. However, no record of patient information forms or systematic documentation regarding the provision of patient consent was discovered. There was no evidence to suggest that the trials systematically and intentionally damaged patients. The trials were conducted without the knowledge of the public. GDR legislation stipulated that patients must consent to the trials, but no evidence was found to suggest that patients were systematically informed. Documents suggest that at least some of the trials were carried out without patients having a comprehensive understanding of what the trial involved. The GDR agreed to the trials due to impending bankruptcy and Western pharmaceutical companies capitalised on this situation.

\section{INTRODUCTION}

In May 2013, a report in the German news magazine Der Spiegel about pharmaceutical tests on humans brought the issue to international attention. ${ }^{1}$ Since 1990 , various newspapers and television stations have reported that unofficial clinical trials were conducted by Western pharmaceutical companies in Eastern Germany from the 1960s onwards, but none provoked a similar wave of indignation. Reporters claimed that the German Democratic Republic (GDR) had 'sold' its patients as 'guinea pigs' for experiments in exchange for hard currency, for example, for tests on doping effects in premature babies and on treating seriously ill patients with placebo instead of actual drugs. The public debate that followed this revelation was soon taken up by politicians who called for a detailed investigation. ${ }^{2}$ Also, people who claimed to have been used in the clinical trials came forward and demanded clarification. The scandal highlighted the fact that there are still unresolved ethical issues from this period that need to be addressed. Currently, there is a lack of reliable data regarding the extent of the studies, the contracts, the amount of money paid, and moral issues such as patient education and informed consent. Some of the drugs tested are still on the market today. This investigation is especially timely given that the relevant 30-year obligatory legal period of patient record retention has begun to expire.

A historical and ethical evaluation of the pharmaceutical trials in the GDR can only be carried out by studying the facts systematically and independently. Therefore, we assessed the nature of the contracts and their legal basis, the circumstances of the remuneration in hard currency, the number of the trials and trial procedures, and the pharmaceutical companies and clinical institutions involved. Our investigation is the first to systematically detail the clinical studies carried out under the German communist regime, their extent and their political context. Scientific research on the GDR healthcare system is just beginning. The use of the GDR health system as a means to provide the country with badly needed hard currency has not yet been systematically investigated.

\section{HISTORICAL CONTEXT}

The GDR health system was heralded as one of the big achievements of socialism. ${ }^{3}$ However, in the 1980 s, the health system was on the brink of financial breakdown, as was the national economy. This resulted in the national health system having to generate hard currency for the state economy, mainly by means of immaterial exports (IME) through the training of specialists, medical treatment of foreign patients, the sale of blood plasma and, from 1983 on, the clinical testing of drugs and medical equipment. ${ }^{4}$ Drugs from the West had been tested in the GDR as early as the 1960s, with these tests carried out and recorded systematically from 1983 onwards. According to the secret report of a medical officer, the initial intention of this ministerial initiative was to conduct clinical studies for the West on 'chosen subjects and to a very small extent', so that 'the GDR would not become a testing ground for West German and American pharmaceutical companies'. 5

\section{METHODS}

We have studied pharmaceutical trials falling under the IME initiative from 1983 until the reunification of Germany in 1990. Our work is based on archived material from the GDR health system currently stored in the Federal Archive in Berlin (Bundesarchiv, BArch). Most information was taken from the documents of the Consultation Office for Drugs (Imports) established by the former Ministry of Health (BBA). We also evaluated Central Committee of Evaluation for Drug Traffic (ZGA) documents. This agency had to approve the trials 
before they were conducted. Another information source was the archives of the East German Secret Service, the so-called Stasi (BStU; table 1).

The documents in these archives showed that the Stasi collected vast amounts of information about the pharmaceutical trials and the files detailed the responsible staff member(s) and fatal patient cases. More than 200 files were analysed.

\section{CONTRACTS AND LEGAL BASIS}

Several institutions were involved in organising the pharmaceutical trials. ${ }^{4} 7$ The first contact point for Western companies was the BBA. The BBA was heavily involved in the organisation and preparation of the legal contracts. These were signed by the relevant pharmaceutical company and the BBA, and also by the East German company Berliner Import Export GmbH (BIEG). The BIEG was part of the confidential Commercial Coordination (KoKo) division of the GDR foreign exports department and was in charge of the financial aspects of the deals. ${ }^{8}$

The GDR Legal Drug Regulations served as the legal basis for the clinical trials from 1964, later from 1986 plus implementing provisions (the drug laws were specified in 1976 and 1986). ${ }^{6}$ They stipulated that phase I-III medical trials could only be conducted if the participants had been informed about the procedure, its effects and risks, and had given their consent. The 1986 amendment additionally required that both the doctor and the patient in phase I and II trials sign a written protocol. In addition to the GDR laws, some Western pharmaceutical companies insisted on including an informed consent clause in their contracts, while others did not. ${ }^{9} 10$

Approval from ZGA was also required and was conditional on two specialist reports being positive. ${ }^{6}$ The ZGA acted as the central ethics board. ${ }^{7}$ Agreed financial compensation for the trials was set out in standard written contracts. The payment itself was made in hard currency to the BIEG, which kept approximately half of the total received $^{7}$; the investigated documents did not indicate what happened to this money. The remaining amount was distributed between the Ministry of Health, the Ministry of Higher Education and Investigation, and the Academy of Sciences. There was no obligation to share any profits with the participating institutions. However, bonus payments in GDR currency were given to individual doctors and hospital teams to increase motivation. ${ }^{11}$ Patients did not receive any monetary compensation for their participation.

\section{NUMBERS OF TRIALS, TRIAL PROCEDURES, CLINICAL INSTITUTIONS, PATIENTS INVOLVED AND WESTERN COMPANIES}

The documentation found reveals the size of the trials. Between 1983 and 1990, at least 220 clinical trials were conducted using drugs manufactured by Western companies. ${ }^{12}$ A range of drugs was tested, including chemotherapeutic agents, insulin, heparin, anti-depressants, anti-allergy drugs, as well as contrast agents and toothpastes. Hundreds of patients were involved in clinical trials of cardiovascular drugs, which were among the most expensive studies and resulted in a number of deaths. This was probably due to the fact that an inclusion criterion for participants in some of these double-blind studies was the presence of a severe New York Heart Association (NYHA) class III-IV heart condition. ${ }^{13}$

Many studies were carried out in multiple institutions simultaneously. Six studies included a follow-up study, while nine studies were stopped prematurely; the reasons for these decisions were not documented in the investigated files. The majority of the studies were phase II and phase III trials. Many of the clinical studies were placebo-controlled double-blind trials investigating new drugs. ${ }^{6}$

Studies were conducted in at least 94 different institutions. An official paper listed 185 separate departments that were involved. ${ }^{6}$ The majority of studies were conducted in the nine medical faculties of the GDR, mainly Humboldt University in Berlin, the Charité (at least 55 trials), and the Medical Academies of Dresden (45), Magdeburg (35) and Rostock (35). We found no evidence to suggest that trials were conducted in other government institutions such as orphanages, prisons or military establishments.

The exact number of participating patients is unknown, but we found documentation showing that the trials included over 14000 participants of all ages, some of whom died during the trials. For example, 22 patients died during a series of trials of vinpocetine (Thiemann) used in stroke patients. ${ }^{14}$ The documents do not indicate whether these deaths were conclusively linked to the clinical trials.

Sixty-eight Western companies participated in the trials, mainly from German speaking countries. The contracts contain details on the financial payments for 217 clinical studies (figure 1). Between 1983 and 1990, the GDR health system received approximately DM 16.5 million for the clinical trials.

\section{DISCUSSION}

\section{Evaluation from a historical perspective}

The tests were generally cost effective for Western pharmaceutical companies, as the GDR was highly dependent on the

Table 1 Governmental agencies and initiatives

\begin{tabular}{|c|c|c|}
\hline $\begin{array}{l}\text { Governmental agency or initiative } \\
\text { (English translation) }\end{array}$ & $\begin{array}{l}\text { Abbreviation } \\
\text { (German) }\end{array}$ & Comment \\
\hline Berliner Import Export & BIEG & $\begin{array}{l}\text { German Democratic Republic (GDR) company, under the control of the KoKo, which laid down the } \\
\text { financial terms of the contracts with Western companies }\end{array}$ \\
\hline $\begin{array}{l}\text { Central Committee of Evaluation for Drug } \\
\text { Traffic }\end{array}$ & ZGA & $\begin{array}{l}\text { Scientific committee of pharmacists and doctors which served as a central ethics board and had to } \\
\text { approve the trials }\end{array}$ \\
\hline Commercial Coordination & KoKo & Confidential division of the GDR foreign exports department (Ministry of Foreign Trade) \\
\hline Consultation Office for Drugs (Imports) & BBA & $\begin{array}{l}\text { Agency of the GDR Ministry of Health that organised the pharmaceutical trials and signed the contracts } \\
\text { with Western companies }\end{array}$ \\
\hline Immaterial Export & IME & $\begin{array}{l}\text { Official phrase used by the GDR to mean the provision of services and products by the GDR as a means } \\
\text { of generating hard currency }\end{array}$ \\
\hline $\begin{array}{l}\text { Ministerium für Staatssicherheit ('Secret } \\
\text { Service') }\end{array}$ & Stasi, MfS & $\begin{array}{l}\text { Secret service of the GDR. Today the files of the Stasi are kept by the governmental authority BStU } \\
\text { (Bundesbeauftragter für die Unterlagen der Staatssicherheit/Federal Commissioner for the Records of the } \\
\text { State Security Service of the Former GDR) }\end{array}$ \\
\hline
\end{tabular}


Figure 1 Participating Western pharmaceutical companies with at least five contracts or paid over DM 0.5 million for drug testing together with the number of signed contracts.

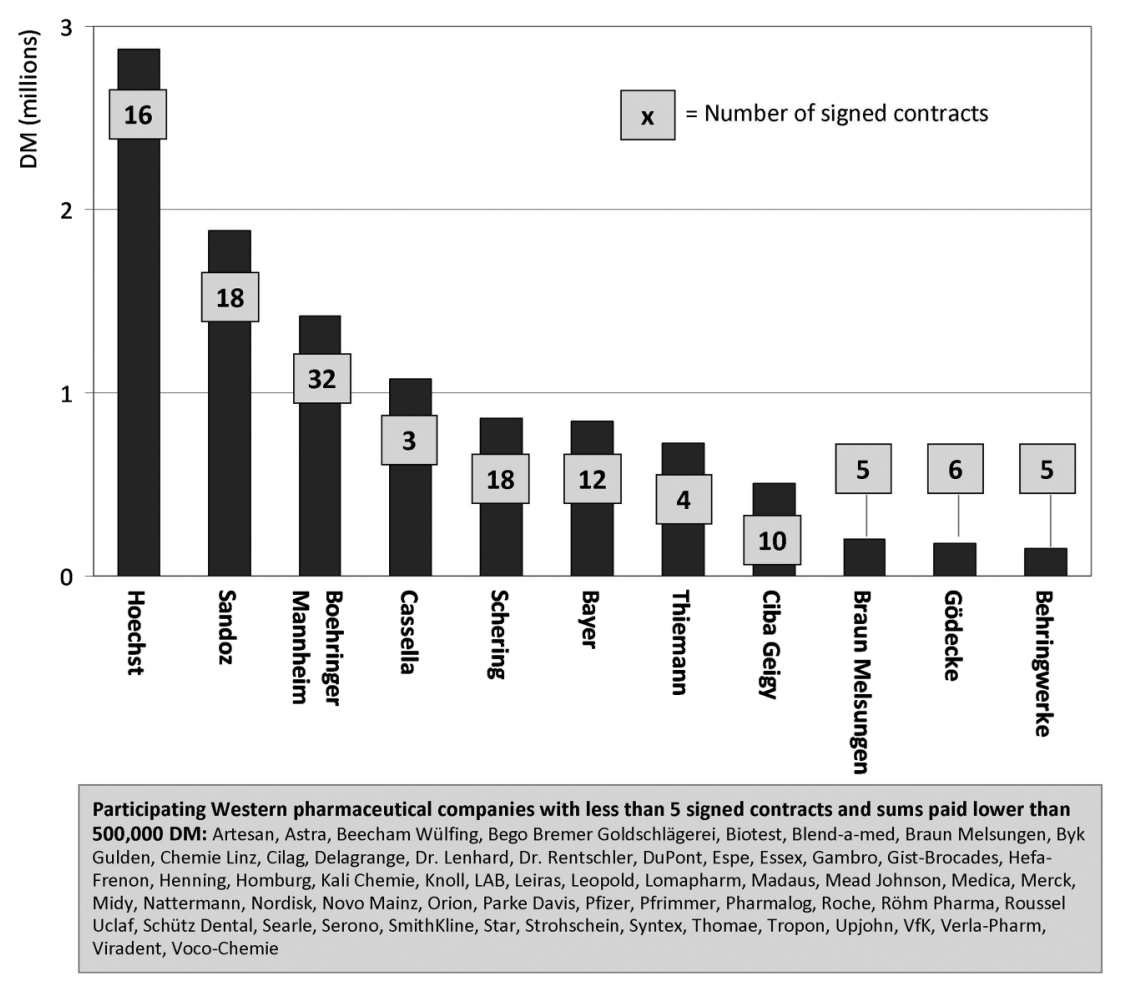

money received for them. Even though some legal regulations were strict (eg, there was an obligation to seek ministerial approval), the GDR was fairly obliging due to its desperate need for hard currency. As a result, pharmaceutical companies were able to legally test new drugs, while at the same time opening up new markets in the Eastern Bloc and getting test results faster and more cheaply than they could elsewhere. ${ }^{15}$

Overall, the files suggest that the GDR attempted to conduct trials according to international ethical standards. We did not find any evidence of procedures that systematically and intentionally damaged patients. In fact, several documents show that the responsible health authorities demanded unconditional protection of patients. ${ }^{6} 1617$ However, it remains unclear whether the patients themselves knew that they were participating in trials and were aware of all risks. Some contracts contained a clause stating that information about the drugs should only be known to the trial conductor. Despite intensive searches in the national archives, no completed patient information forms were found or systematic documentation regarding the provision of written or oral patient consent. These findings contrast with the report of a Berlin investigation commission in 1991 which had only a short time for research and provided very limited results. ${ }^{18} \mathrm{~A}$ pilot investigation of patient reports from the University of Jena in 2013 suggested that some patients knew about their participation in clinical trials of a non-approved antidepressant. ${ }^{19}$ However, no evidence could be found to explain how these patients were actually informed. This is surprising, given that the BBA officially stipulated that patient information protocols should include a written declaration of consent for all Western studies, at least from January 1988 onwards. ${ }^{6}$ However, neither the medical records nor other investigated files showed evidence of a standardised procedure. Similarly, a search of the files of the German Federal Institute for Drugs and Medical Devices (BfArM), the German institution responsible for approving new drugs, shed no light on these specific issues. Novartis, the responsible pharmaceutical company, rejected participation in the University of Jena pilot study.
In February 1988, state officials criticised doctors' apparent lack of knowledge concerning national drug regulations and particularly their obligation to inform patients. ${ }^{20}$ It remains unclear why, in November 1988, the Ministry of Health demanded that doctors once again ask patients for 'oral and written consent' in order to 'avoid political discussions' with them 'amongst other reasons'. ${ }^{6}$

The responsible government agencies showed an increasing interest in discussing international standards for clinical trials. As late as 1989, the Ministry of Health decided that Western inspectors should be allowed into the country and that the international quality standards for clinical trials (good clinical practice (GCP) regulations) should be upheld in the GDR. ${ }^{6}$

It is important to note that the secret service was very well informed about the clinical trials. The Stasi had unofficial collaborators in all important areas of the system who kept their superiors well informed. ${ }^{15} 21-25$ The documents show that critical discussions between doctors involved in the trials considered whether the GDR had become a cheap testing ground for the West. ${ }^{26} 27$

\section{Ethical evaluation}

The general moral problem is that the pharmaceutical trials were carried out without the public being informed. Specifically, the commercial transactions were conducted without the knowledge of East German citizens, in order to serve the economic interests of a country that was fast approaching financial bankruptcy. $^{7}$ Of course, testing without patient consent would be far more serious. However, we could not conclusively determine whether or to what extent patients were informed. On the one hand, the study conducted by the University Jena showed that some patients knew that they had taken part in a trial. On the other hand, we could not find any information sheets for patients. In addition, the fact that officials demanded a clearer patient information process suggests that at least some of the 
trials were conducted illegally. This assumption, however, remains speculative.

An aggravating factor was that the GDR ideology required the subordination of the individual to the interests of the collective, a basic precept of Marxism. ${ }^{28}$ Therefore, the rights of the individual were not always fully taken into account. This goes against traditional medical ethics where patient autonomy is the primary concern. In the GDR, decisions were often made for purely ideological reasons. ${ }^{29}$ State politics followed a socialist collective code of ethics and ethical freedom was nonexistent, a fact that even formerly loyal GDR ethicists openly admit today. ${ }^{30}$ Medical employees, doctors and scientists were expected to subordinate their interests to prioritise tasks of importance to society. ${ }^{31}$ A truly independent medical opinion was not wanted. Given these external conditions, the potential risks of using unapproved drugs or of conducting double-blind randomised placebo-controlled trials were secondary considerations. ${ }^{32}$ One could argue that medical ethics principles change when we do not regard autonomy as being paramount and that the approach of the GDR Ministry of Health might be justified on these grounds. However, following this line of argument requires recognition of the norms and values of the socialist society of the GDR. In this sense, bioethical discussion cannot be separated from socio-critical debate.

With no information given to the public and no public dialogue, patients in the GDR were hardly aware of their own rights and responsibilities. The origin of the bioethical problem lies in the special relationship between doctor and patient. Specifically, patients expect the doctor to cure them or at least to have their best interests at heart. Patients are highly dependent on doctors' medical decisions, which patients are aware they often do not understand. Witnesses report that East German doctors usually welcomed the opportunity to use modern drugs, especially if they were supplied by the supposedly 'better' Western world. Doctors were, therefore, 'emotionally' very much in favour of their patients participating in these trials. This had consequences. In a society requiring subordination of the individual to the interests of the collective, renunciation of autonomy meant increased dependence on authorities, in this case, the medical authorities. ${ }^{33}$

With respect to the clinical trials, the patients had to choose whether or not to participate although given little time to decide, providing they were given the chance to carefully consider this decision at all.

Another critical point was that the GDR health system was obliged to generate income in hard currency. The state saw the health sector not as promoting patient well-being as a central concern but rather as providing an opportunity to earn muchneeded hard currency. The contracts between the East and West were not primarily drawn up by medical or pharmaceutical professionals but by the GDR foreign trade department under the direct control of the Stasi.

Importantly, most medical facilities were experiencing a general supply shortage. ${ }^{34}$ Those in charge, therefore, normally went out of their way to accede to any requests made by the state. Moreover, they would be paid for their participation in the trials, albeit in local currency.

Of course, the problem can only be evaluated within the general context of the morality of a dictatorial state. In the GDR, health care was organised by the state. The goal was an almost free, centrally planned healthcare system, equally available to every citizen. The healthcare system was seen as one of the major achievements of the country. Even today many are convinced that the East German health system was one of the more important benefits of the GDR. ${ }^{35}$ However, despite the propaganda, the state healthcare system as well as the entire East German economy was barely able to survive in the late 1980s. ${ }^{34}{ }^{36}$ However, the public were unaware of this as the picture of the country presented to its citizens was one of unfailing confidence. ${ }^{37}$

An example illustrates this highly problematic lack of consideration of human and patients' rights. Before the West German Chancellor, Helmut Schmidt visited the GDR in 1980, the Stasi ordered that 'a list of all mentally disturbed citizens in the district' be created and that the affected people should not be informed. The fact that such a demand completely disregarded medical confidentiality was of no concern to the state. ${ }^{3}$

This system often falsified the past, the present and the future, ${ }^{37}$ so it was impossible for citizens to determine the truth. In such a situation, it was difficult for anyone to make an independent decision, especially since public opinion was extensively manipulated and controlled. Consequently, the state had no interest in a public debate on clinical trials and their reasons. This fact suited the Western pharmaceutical companies very well. They took advantage of the submissiveness of GDR officials and doctors, which facilitated a smooth process without public debate. This may have played a key role in company decisions to test their drugs in Eastern Germany. For instance, Roussel Uclaf conducted two trials of mifepristone, a drug used for medical abortion, in the GDR: in 1988, the company stopped distribution of this drug in France after anti-abortion protests but simultaneously began a trial in the GDR. ${ }^{9}$

\section{The media and conclusions}

Health is important to all of us and medical research in particular often causes controversy. The media are always ready to accuse researchers of exploiting vulnerable 'human guinea pigs' ${ }^{38}$ In addition, we are discussing a contentious period of recent history.

Of course, public interest sparked by the media is welcomewe need public interest so that research is supported. However, the fierce controversy ignited by the Der Spiegel article shows that the issue is unresolved and further investigation is urgently needed. Certainly, we need critical reports to shed light on ethical violations. However, in this case the media sensationalisation of the trials seems unjustified: the reports were tendentious, distorted and in many cases incorrect. This can be clearly illustrated by two examples.

Drugs used in clinical trials involving erythropoietin in preterm infants were described as doping substances. ${ }^{1}$ The use of the term 'doping' is misleading as the fact that erythropoietin is essential for red blood cell production was omitted. The report implied that the conduction of these trials was criminal, thus prejudicing the impartiality of any reappraisal. A second example concerns the deaths of patients. Newspapers reported various numbers of fatalities, usually without reference to the fact that many of the patients were already seriously ill. ${ }^{39}$ This material concealment is, of course, unacceptable from a scientific perspective and leads to wrong conclusions.

The term 'human experiment' is also inappropriate in this context. ${ }^{40}$ Reference to Nazi crimes where doctors coerced prisoners to participate in trials without consent usually with the acceptance or even the aim of killing the participants, has nothing to do with the clinical studies in the GDR. Such a comparison is highly negligent and can trivialise crimes and serious human rights violations even if the basic problem is one of consent in both cases. 
People from different backgrounds are trying to come to terms with the history of the GDR. Therefore, accounts of East Germany history should meet scientific and not ideological standards. We need reliable results and objective investigation in order to deepen our historical and ethical understanding. Currently, there is very little independent research on the GDR healthcare system of the 1980s. Specific trials now need to be studied separately. Particular incidents, for example deaths, must be considered as part of a meticulous examination of individual case studies. The medical profession has an ethical obligation to participate in future investigations, which should not be left to the media.

Acknowledgements We would like to acknowledge the contribution of Alexandra Murray and Heike Erices for their valuable discussion and revisions to the manuscript.

\section{Competing interests None.}

Provenance and peer review Not commissioned; externally peer reviewed.

Data sharing statement The data reported in the paper are archived in the Federal Archives of Germany, Bundesarchiv, and in the archives of the Bundesbeauftragter für die Stasi-Unterlagen/BStU (Federal Commissioner for the Records of the State Security Service of the Former German Democratic Republic/GDR)

\section{REFERENCES}

1 Kuhrt N, Wensierski P. Günstige Teststrecke. Der Spiegel 13 May 2013:38-45.

2 http://www.dw.de/unwissende-probanden-medikamententests-in-der-ddr/ a-16812503. Wewetzer H, Müller-Lissner A. Mit Risiken und Nachwirkungen. Der Tagesspiegel 13 May 2013. http://www.gesundheitsstadt-berlin.de/nachrichten/ artikel/medikamententests-fanden-ddr-weit-statt-1578/. http://www.saskia-ludwig. de/image/inhalte/file/120_130514_Ludwig_Eichelbaum_Pharmatests.pdf. Finger E, Hamann G. Übler deutsch-deutscher Deal. Die Zeit 16 May 2013.

3 Erices R. Ein kaum zu lösendes Problem. Das DDR-Gesundheitswesen in den Bezirksarzt-Akten der Staatssicherheit. Gerbergasse 18. Forum für Geschichte und Kultur 2013;66:26-33.

4 BArch DQ 1/13175.

5 BStU, MfS, BV Neubrandenburg, AIM, Nr. 505/88, II/1, p. $117 f$.

6 BArch DQ 1/14477

7 BArch DQ 105/24.

8 Buthmann R. Die Arbeitsgruppe Bereich Kommerzielle Koordinierung (MfS-Handbuch). Berlin, 2004.

9 BArch DQ 108/96.

10 BArch DQ 105/32.

11 BArch DQ 105/54.

12 BArch DQ 108/89.

13 BArch DQ 108/95, 2/2.

14 BArch DQ 108/94, $1 / 2$.

15 BStU, MfS, BV Berlin, Abt. XX, Nr. 2789.

16 BArch DQ 108/93, 1/2.
17 BArch DQ 1/14470.

18 Anonymous. Arzneimittelprüfungen in Ost-Berlin. Berliner Ärzte October 1991:16-23

19 Press release: Arzneimittelstudien in der DDR: Arbeitsgruppe am UKJ legt Verfahrensvorschlag zur Überprüfung der DDR-Studien vor. Jena University Hospital, 21 Oct 2013. http://www.uniklinikum-jena.de/Startseite/Aktuelles_Presse/Presse/ Aktuelle+Pressenews/Arzneimittelstudien+in+der+DDR_+Arbeitsgruppe+am+UKJ +legt+Verfahrensvorschlag+zur+\%C3\%9Cberpr\%C3\%BCfung+der+DDR_Studien +vor-p-42544.html (accessed 9 Sept 2014).

20 BArch DQ 108/90, 1/2

21 BStU, MfS, AIM, Nr. 8276/91.

22 BStU, MfS, AIM, Nr. 12750/83.

23 BStU, MfS, HA XX, Nr. 6899.

24 BStU, MfS, HA XX, Nr. 47, $1 / 2$.

25 BStU, MfS, HA XX, Nr. 44, 1/3.

26 BStU, MfS, Sekr. Mittig, Nr. 156, 2/2, XX, 238-239.

27 BStU, MfS, BV Berlin, AGMS, Nr. 4314/91, XX, 260-261.

28 Quitz A. Staat, Macht, Moral. Die medizinische Ethik in der DDR [dissertation]. Erlangen: Friedrich-Alexander-Universität Erlangen-Nürnberg, 2013.

29 Wolle S. Die heile Welt der Diktatur: Alltag und Herrschaft in der DDR 1971-1989. Berlin: Ch. Links, 2013.

30 Luther E. Abriss zur Geschichte der medizinischen Ethik in der DDR. In: Bettin H, Gadebusch Bondio M, eds. Medizinische Ethik in der DDR. Erfahrungswert oder Altlast? Lengerich: Pabst Science Publishers, 2010:20-39.

31 Schlich T. Degrees of control: the spread of operative fracture care with metal implants. A comparative perspective on Switzerland, East Germany and the USA, 1950s-1990s. In: Stanton J, ed. Innovations in health and medicine: diffusion and resistance in the twentieth century. London: Routledge, 2002:106-25.

32 Kopelman L. Consent and randomized clinical trials: are there moral or design problems? J Med Philos 1986;11(4):317-45.

33 Kerz-Rühling I, Plänkers T. Verräter oder Verführte. Eine psychoanalytische Untersuchung Inoffizieller Mitarbeiter der Stasi. Berlin: Ch. Links, 2004. Geyer M, ed. Psychotherapie in Ostdeutschland. Geschichte und Geschichten 1945-1995. Göttingen: Vandenhoeck \& Ruprecht, 2011

34 Erices R, Gumz A. Das DDR-Gesundheitswesen in den 1980er Jahren: Ein Zustandsbild anhand von Akten der Staatssicherheit. Health-Care Services in the GDR during the 1980s: A Status Report Based on the Files of the State Security Agency. Das Gesundheitswesen 2014;76:73-8.

35 Friedrich-Naumann-Stiftung [Internet]. Deutscher Wertemonitor 2008. Zusatzfragen zum Themenkreis DDR. 2009. http://www.freiheit.org/files/62/DDRDiagramme.pdf

36 Freudenstein $U$, Borgwardt $G$. Primary medical care in former East Germany: the frosty winds of change. BMJ 1992;304:827-8.

37 Sperlich PW. Oppression and scarcity: the history and institutional structure of the Marxist-Leninist government of East Germany and some perspectives on life in a socialist system. Westport: Praeger Publishers, 2006.

38 Brazier M. Exploitation and enrichment: the paradox of medical experimentation. J Med Ethics 2008;34:180-3.

39 http://www.handelszeitung.ch/unternehmen/schweizer-pharma-tote-beimenschenversuchen-ddr

40 Schmidt U, Frewer A, eds. History and theory of human experimentation. The Declaration of Helsinki and Modern Medical Ethics. Stuttgart: Franz Steiner Verlag, 2007. 


\section{ME Testing ground GDR: Western pharmaceutical firms conducting clinical trials behind the Iron Curtain}

Rainer Erices, Andreas Frewer and Antje Gumz

J Med Ethics 2015 41: 529-533 originally published online October 23, 2014

doi: 10.1136/medethics-2013-101925

Updated information and services can be found at:

http://jme.bmj.com/content/41/7/529

These include:

Supplementary Supplementary material can be found at:

Material http://jme.bmj.com/content/suppl/2014/10/21/medethics-2013-101925 .DC1

References This article cites 5 articles, 2 of which you can access for free at: http://jme.bmj.com/content/41/7/529\#BIBL

Email alerting service

Receive free email alerts when new articles cite this article. Sign up in the box at the top right corner of the online article.

Topic Articles on similar topics can be found in the following collections Collections

Press releases $(36)$

\section{Notes}

To request permissions go to:

http://group.bmj.com/group/rights-licensing/permissions

To order reprints go to:

http://journals.bmj.com/cgi/reprintform

To subscribe to BMJ go to:

http://group.bmj.com/subscribe/ 